\title{
Correction to: Water Availability and Management in Mexico
}

Elena María Otazo-Sánchez, Amado Enrique Navarro-Frómeta and Vijay P. Singh

\section{Correction to:}

E. M. Otazo-Sánchez et al. (eds.), Water Availability

and Management in Mexico, Water Science

and Technology Library 88,

\section{https://doi.org/10.1007/978-3-030-24962-5}

In the original publication of this book, the volume number was incorrect. It should read " 88 " instead of "999". This has now been corrected. 